\title{
First synthesis of meso-substituted pyrrolo[1,2-a]quinoxalinoporphyrins
}

Dileep Kumar Singh and Mahendra Nath*

\section{Full Research Paper}

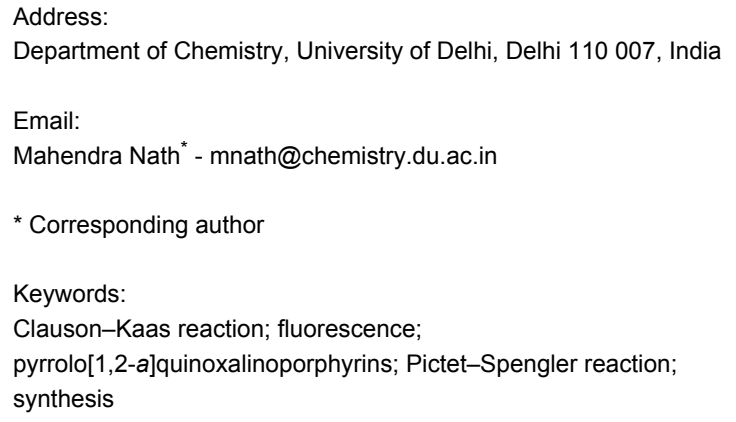

\author{
Beilstein J. Org. Chem. 2014, 10, 808-813. \\ doi:10.3762/bjoc. 10.76 \\ Received: 14 January 2014 \\ Accepted: 17 March 2014 \\ Published: 08 April 2014 \\ Associate Editor: J. P. Wolfe \\ (C) 2014 Singh and Nath; licensee Beilstein-Institut. \\ License and terms: see end of document.
}

\begin{abstract}
A synthetic protocol for the construction of new meso-substituted pyrrolo[1,2- $a$ ]quinoxalinoporphyrins is described starting from 5-(4-amino-3-nitrophenyl)-10,15,20-triphenylporphyrin. The reaction of this porphyrin with 2,5-dimethoxytetrahydrofuran, followed by the reduction of the nitro group in the presence of $\mathrm{NiCl}_{2} / \mathrm{NaBH}_{4}$ afforded 5-(3-amino-4-(pyrrol-1-yl)phenyl)-10,15,20-triphenylporphyrin. This triphenylporphyrin underwent a Pictet-Spengler cyclization after the reaction with various aromatic aldehydes followed by in situ $\mathrm{KMnO}_{4}$ oxidation to form target porphyrin analogues in good yields. The structures of all synthesized products were established on the basis of spectral data and elemental analyses.
\end{abstract}

\section{Introduction}

Many natural porphyrins are known to play essential roles in a number of biological processes including oxygen transport [1], solar energy conservation [2-4] and photosynthesis [5]. Owing to the expanded $\pi$-conjugation system as well as good thermal stabilities, various artificial porphyrins have been prepared as promising materials for organic photonic and electronic applications [6-9]. In addition, porphyrins fused with external aromatic systems exhibit a broad range of applications in diverse areas such as molecular devices [10-13], organic light emitting diodes [14,15], near infrared dyes [16-18], hybrid solar cells [19-22], and biosensors [23-25] due to their intense optical absorptions and photoluminescence characteristics. On the other hand, com- pounds containing a pyrrolo[1,2- $a]$ quinoxaline subunit display a wide spectrum of biological profiles as antagonists [26,27], PARP-1 inhibitors [28], anticancer agents [29,30], anti-HIV agents [31], and antimalarial agents [32,33]. These molecules are also important intermediates for the construction of $5-\mathrm{HT}_{3}$ receptor agonists [34,35] and are useful as fluorescent materials for various applications [36,37].

In recent years, numerous covalent or non-covalent supra-porphyrin arrays, based on donor-acceptor architectures have been constructed for mimicking the natural photosynthetic light harvesting systems [38-40]. Additionally, a variety of bio- 
logically important functional groups were also introduced on the periphery of meso-substituted porphyrins to develop efficient photosensitizers for photodynamic therapy applications [41-43]. However, the porphyrins with a pyrrolo[1,2-a]quinoxaline moiety at the meso-positions have not been synthesized and their photophysical properties have not been evaluated yet. By considering the biological and fluorescent properties of these two classes of heterocycles, we envisaged to combine both porphyrin and pyrrolo[1,2-a]quinoxaline units in a single molecular framework to generate novel meso-substituted pyrrolo[1,2a]quinoxalinoporphyrin analogues. Such hybrid molecules may prove useful for various biological studies and in the development of new photodynamic agents. Therefore, in continuation of our efforts to develop simple and efficient methods [44-48] for the synthesis of diverse porphyrin derivatives from mesotetraarylporphyrins, we wish to report herein the first synthesis and spectroscopic properties of a novel series of meso-substituted pyrrolo[1,2-a]quinoxalinoporphyrins.

\section{Results and Discussion}

The synthetic strategy for targeted meso-substituted pyrrolo[1,2-a]quinoxalinoporphyrins $(\mathbf{4 a - h})$ is depicted in Scheme 1. At first, 5-(4-amino-3-nitrophenyl)-10,15,20-triphenylporphyrin (1) was synthesized from 5,10,15,20-tetraphenylporphyrin (TPP) after a series of reactions $[46,49]$ in five steps. The Clauson-Kaas reaction of porphyrin (1) with 2,5-<smiles></smiles>

1

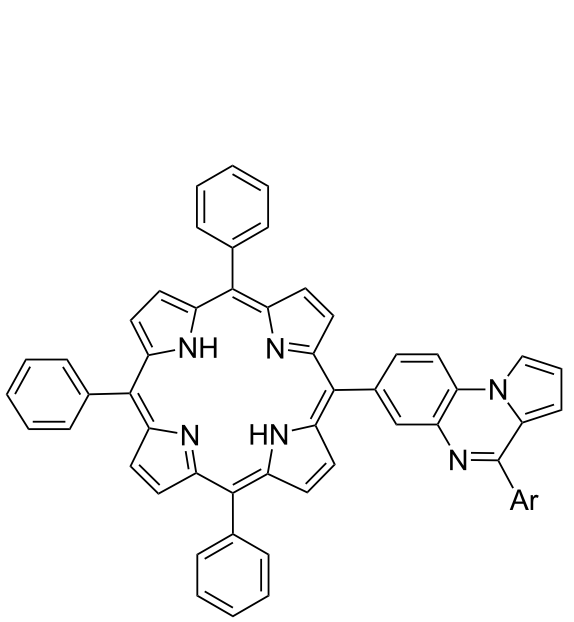

$4 a-h$

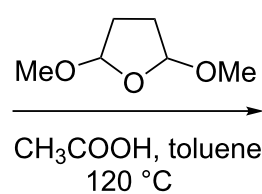
$120^{\circ} \mathrm{C}$

1. $\mathrm{ArCHO}, 2 \% \mathrm{TFA}$, $\mathrm{CH}_{2} \mathrm{Cl}_{2}, 0^{\circ} \mathrm{C}$

2. $\mathrm{KMnO}_{4}, 25^{\circ} \mathrm{C}$

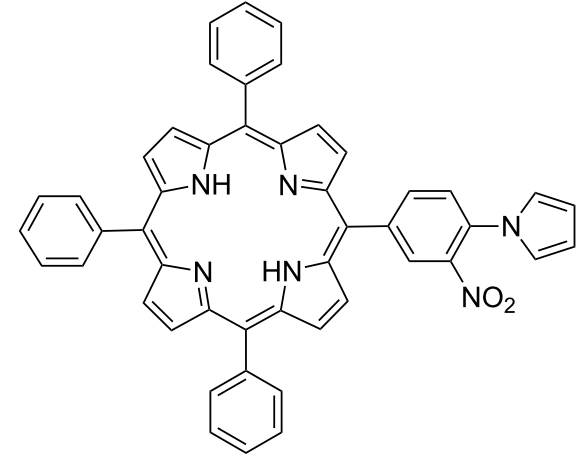

2

$\mathrm{NiCl}_{2}, \mathrm{NaBH}_{4}$

$\mathrm{CH}_{2} \mathrm{Cl}_{2}, \mathrm{CH}_{3} \mathrm{OH}$ $25^{\circ} \mathrm{C}$

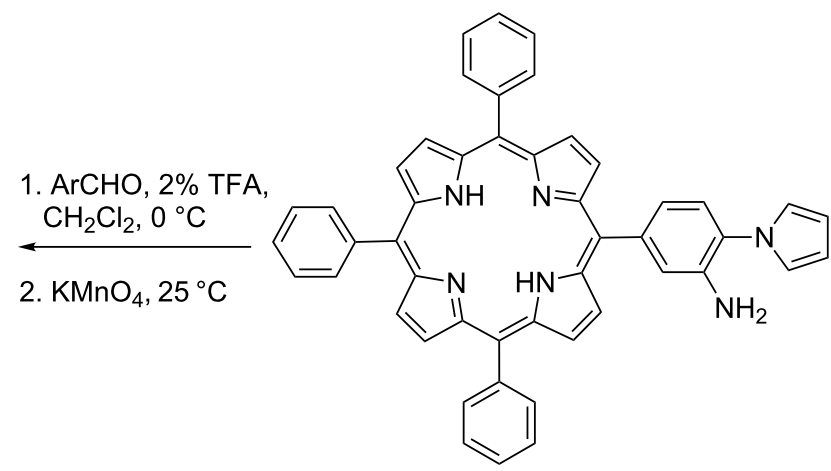

3

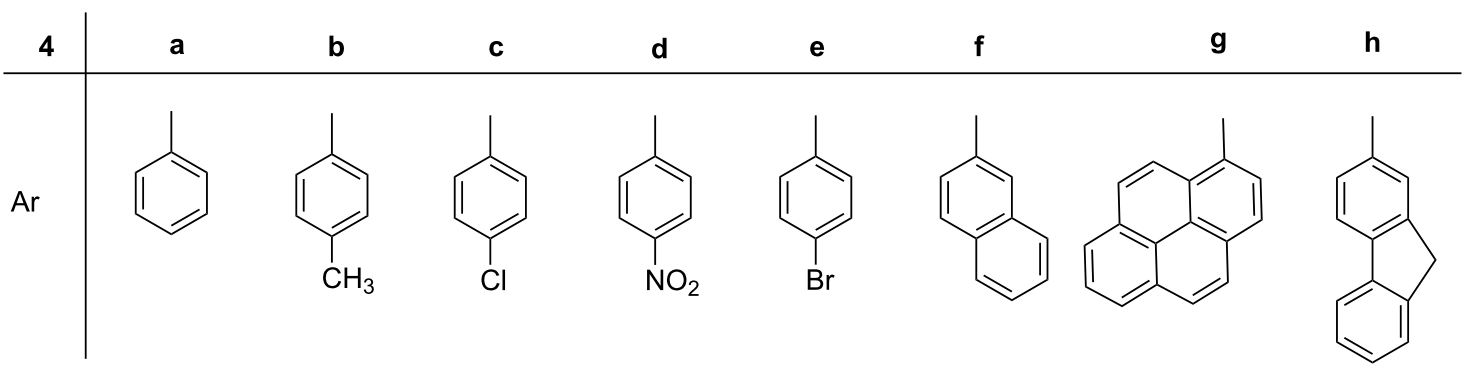


dimethoxytetrahydrofuran in toluene/acetic acid mixture afforded novel 5-(3-nitro-4-(pyrrol-1-yl)phenyl)-10,15,20-triphenylporphyrin (2) in $89 \%$ yield. The reduction of nitroporphyrin 2 was initially carried out by using $\mathrm{Sn} / \mathrm{HCl}, \mathrm{SnCl}_{2} \cdot 2 \mathrm{H}_{2} \mathrm{O} /$ $\mathrm{HCl}$, and $\mathrm{Pd} / \mathrm{C}-\mathrm{NaBH}_{4}$ as reducing agents but the reaction was found to be sluggish and provided an inseparable mixture of products. Instead, nitroporphyrin $\mathbf{2}$ was successfully reduced to 5-(3-amino-4-(pyrrol-1-yl)phenyl)-10,15,20-triphenylporphyrin (3) in the presence of nickel boride, generated in situ by the reaction of $\mathrm{NiCl}_{2}$ and $\mathrm{NaBH}_{4}$ in a $\mathrm{CH}_{2} \mathrm{Cl}_{2} / \mathrm{MeOH}$ mixture at $25{ }^{\circ} \mathrm{C}$. Finally, the synthesis of novel meso-substituted pyrrolo[1,2-a]quinoxalinoporphyrins $(\mathbf{4 a}-\mathbf{h})$ began via the Pictet-Spengler cyclization reaction [50,51] of 5-(3-amino-4(pyrrol-1-yl)phenyl)-10,15,20-triphenylporphyrin (3) with various aromatic aldehydes by using $2 \%$ TFA in dichloromethane as an acidic catalyst at $0{ }^{\circ} \mathrm{C}$ for 5 minutes, followed by aromatization in the presence of $\mathrm{KMnO}_{4}$ at room temperature (Scheme 1).

The target products were purified by column chromatography over neutral alumina and obtained in $60-76 \%$ isolated yields. Furthermore, the $\pi$ electron-rich free-base porphyrin dyads (4g and $4 \mathrm{~h}$ ) were converted to the corresponding zinc(II) porphyrins (5 and 6) in 84 and $87 \%$ yields, respectively, after the treatment with $\mathrm{Zn}(\mathrm{OAc})_{2} \cdot 2 \mathrm{H}_{2} \mathrm{O}$ in $\mathrm{CHCl}_{3} / \mathrm{MeOH}$ mixture for 30 minutes at room temperature (Scheme 2).

All synthesized porphyrins (2, 3, 4a-h, $\mathbf{5}$ and $\mathbf{6})$ were characterized on the basis of NMR, IR, UV-vis and mass spectral data in addition to elemental analysis. The proton NMR of newly prepared free-base meso-substituted pyrrolo[1,2-a]quinoxalinoporphyrins $(\mathbf{4 a}-\mathbf{h})$ showed a characteristic singlet around $\delta$ $-2.7 \mathrm{ppm}$ for two NH protons of the porphyrin core. The $\beta$-pyrrolic protons of the porphyrin ring appeared in the downfield region between $\delta 8.85-9.01 \mathrm{ppm}$. A characteristic doublet at $\delta 8.9$ and a double doublet at $\delta 8.3 \mathrm{ppm}$ were assigned to the C-2 and C-6 protons of the meso-phenyl ring fused with the pyrroloquinoxaline moiety. The $\mathrm{C}-5$ proton was found to be merged with nine other meso-phenyl protons and appeared as a multiplet between $\delta 7.75-7.77 \mathrm{ppm}$. The remaining six meso-phenyl protons appeared as a multiplet between $\delta 8.20-8.25 \mathrm{ppm}$ along with a pyrrolic $\mathrm{C}-1^{\prime}$ proton. In the case of porphyrins (4a-f), the two pyrrolic C-2' and C-3' protons of the pyrroloquinoxaline ring appeared as a double doublet at around $\delta 7.06 \mathrm{ppm}$ and a doublet at around $\delta 7.19 \mathrm{ppm}$, respectively. The ${ }^{1} \mathrm{H}$ NMR spectrum of porphyrin $\mathbf{4 g}$ displayed these pyrrolic $\mathrm{C}-2^{\prime}$ and $\mathrm{C}-3^{\prime}$ protons as a double doublet at $\delta 7.01 \mathrm{ppm}$ and a doublet at around $\delta 6.74 \mathrm{ppm}$, whereas these pyrrolic protons appeared as multiplets between $\delta 7.09-7.24 \mathrm{ppm}$ in the case of porphyrin $4 \mathrm{~h}$. In addition, porphyrin $4 \mathrm{~h}$ and 6 showed a characteristic singlet for the $\mathrm{CH}_{2}$ protons of the fluorenyl moiety at $\delta 4.0$ and $3.9 \mathrm{ppm}$, respectively. The IR spectra of all the free-base pyrrolo[1,2-a]quinoxalinoporphyrins showed a peak between $3317-3318 \mathrm{~cm}^{-1}$ due to the NH bond stretching. The structures of porphyrins $(\mathbf{2}, \mathbf{3}, \mathbf{4} \mathbf{a}-\mathbf{h}, \mathbf{5}$ and $\mathbf{6})$ were further supported by mass spectral analysis, which revealed the molecular ion peak to be $[\mathrm{M}+\mathrm{H}]^{+}$. The electronic absorption and emission data of all the synthesized compounds are presented in Table 1.

The UV-vis spectra of newly prepared meso-substituted pyrrolo[1,2-a]quinoxalinoporphyrins $(\mathbf{4 a}-\mathbf{h})$ in chloroform exhibited a typical intense Soret band at $\sim 422 \mathrm{~nm}$ and four weaker Q bands at $\sim 517,552,596$ and $647 \mathrm{~nm}$. In contrast, the zinc(II) pyrrolo[1,2-a]quinoxalinoporphyrin analogues 5 and $\mathbf{6}$ showed an intense Soret band at $\sim 25 \mathrm{~nm}$ and two weaker Q bands at $\sim 553$ and $594 \mathrm{~nm}$. In comparison to the TPP and $\mathrm{Zn}$-TPP, the UV-vis spectra of free-base porphyrins $\mathbf{4 a}-\mathbf{h}$ and zinc porphyrins ( 5 and $\mathbf{6}$ ) were found to be red-sifted by 3 to $4 \mathrm{~nm}$. The electronic absorption spectra of selected free-base

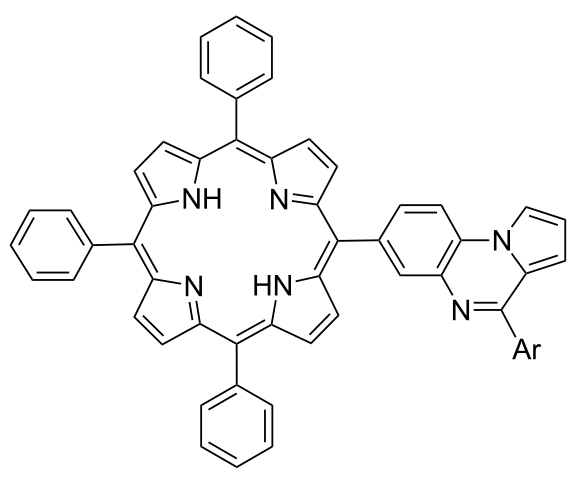

$\mathbf{4 g}$ or $\mathbf{4 h}$

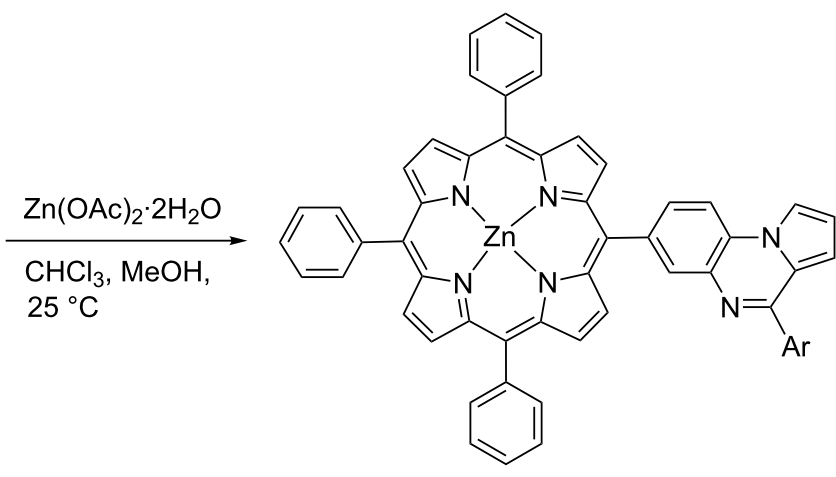

5; $\mathrm{Ar}=1$-pyrene

6; $\mathrm{Ar}=2$-fluorene 
Table 1: Electronic absorption and emission data of porphyrins $(2,3,4 a-h, 5$ and 6$)$.

\begin{tabular}{lll} 
Compound & Absorption ${ }^{\mathrm{a}} \lambda_{\max }, \mathrm{nm}\left(\varepsilon \times 10^{-4}, \mathrm{M}^{-1} \mathrm{~cm}^{-1}\right)$ & Fluorescence ${ }^{\mathrm{a}, \mathrm{b}}\left(\lambda_{\mathrm{em}} / \mathrm{nm}\right)$ \\
\hline $\mathbf{2}$ & $421(56.24), 517(2.82), 551(1.26), 593(0.41), 647(0.54)$ & 651,717 \\
$\mathbf{3}$ & $421(45.66), 517(2.56), 550(1.28), 597(0.31), 647(0.80)$ & 653,717 \\
4a & $422(39.00), 517(2.93), 550(1.84), 597(0.33), 647(0.97)$ & 653,717 \\
$\mathbf{4 b}$ & $422(58.51), 517(3.11), 551(1.63), 594(0.37), 647(0.71)$ & 652,717 \\
4c & $422(51.51), 517(2.36), 552(1.16), 594(0.41), 648(0.59)$ & 652,716 \\
4d & $422(57.74), 517(3.49), 552(1.81), 596(0.30), 648(0.76)$ & 652,715 \\
4e & $422(61.39), 517(3.05), 552(1.53), 597(0.19), 648(0.68)$ & 652,716 \\
$\mathbf{4 f}$ & $423(63.00), 517(3.50), 551(1.91), 597(0.34), 647(0.97)$ & 652,717 \\
$\mathbf{4 g}$ & $422(59.97), 517(3.32), 552(1.82), 596(0.32), 648(0.87)$ & 652,717 \\
$\mathbf{4 h}$ & $423(73.28), 517(3.90), 552(2.07), 596(0.38), 648(0.96)$ & 652,717 \\
$\mathbf{5}$ & $425(104.90), 554(3.80), 594(1.00)$ & 605,652 \\
$\mathbf{6}$ & $425(117.50), 553(4.20), 594(1.20)$ & 606,654 \\
\hline
\end{tabular}

${ }^{\mathrm{a}} \mathrm{Abs}$ rption and emission data were taken for $\mathrm{CHCl}_{3}$ solutions of porphyrins at $298 \mathrm{~K}$. ${ }^{\mathrm{b}} \mathrm{The}$ excitation wavelength for emission data is $420 \mathrm{~nm}$.
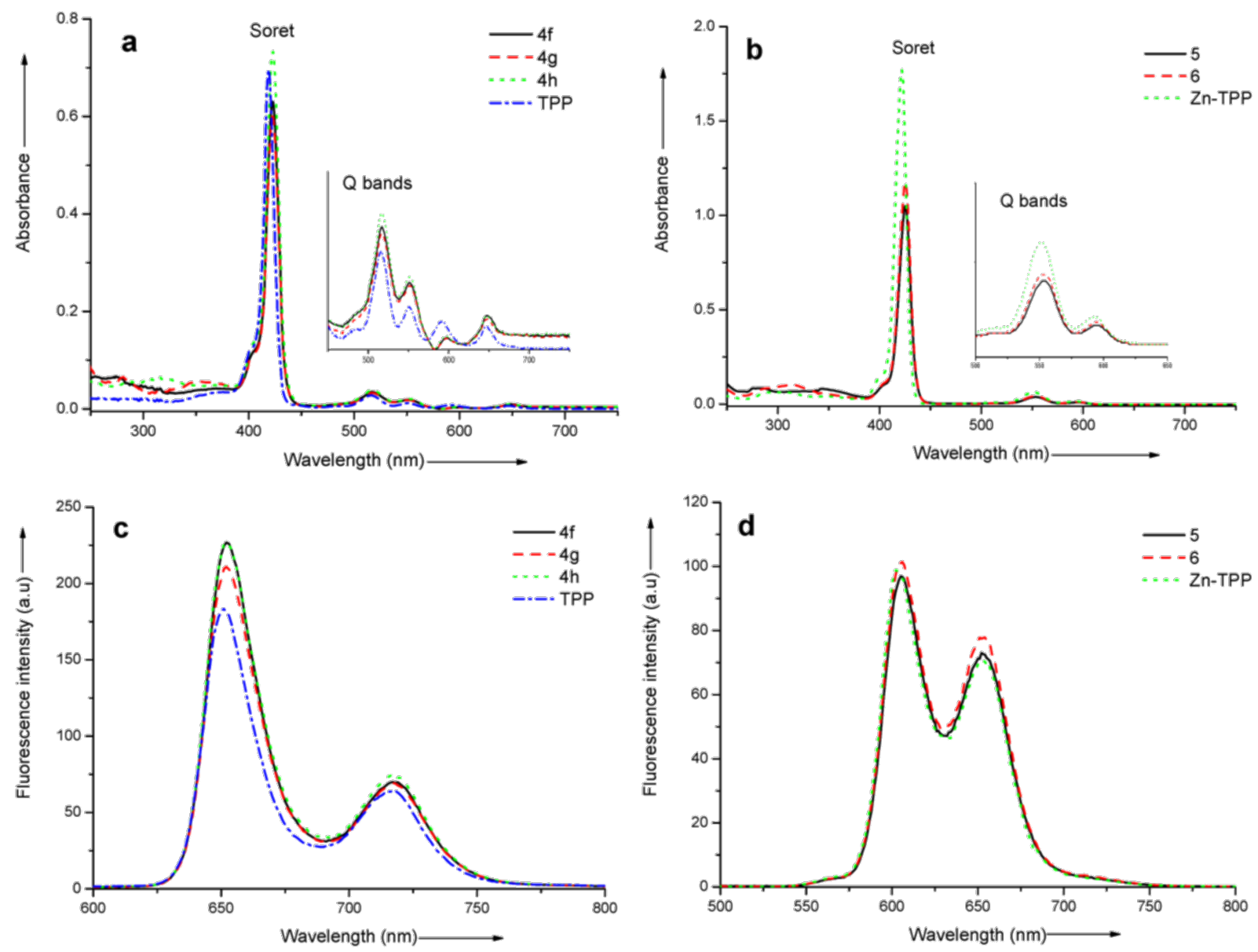

Figure 1: (a) Electronic absorption spectra of free-base porphyrins $\mathbf{4 f}, \mathbf{4 g}, \mathbf{4 h}$ and TPP in $\mathrm{CHCl}_{3}\left(1 \times 10^{-6}\right.$ mol L-1) at $298 \mathrm{~K}$. (b) Electronic absorption spectra of zinc porphyrins (5, 6 and $\mathrm{Zn}-\mathrm{TPP})$ in $\mathrm{CHCl}_{3}\left(2 \times 10^{-6} \mathrm{~mol} \mathrm{L^{-1 }}\right)$ at $298 \mathrm{~K}$. The inset in both (a) and (b) shows the Q bands. (c) Fluorescence spectra of porphyrins $\mathbf{4 f}, \mathbf{4 g}, \mathbf{4 h}$ and TPP in $\mathrm{CHCl}_{3}\left(1 \times 10^{-6} \mathrm{~mol} \mathrm{~L}^{-1}\right)$ at $298 \mathrm{~K}, \lambda_{\mathrm{ex}}=420 \mathrm{~nm}$. (d) Fluorescence spectra of zinc porphyrins $(\mathbf{5}, \mathbf{6}$, and $\mathrm{Zn}-\mathrm{TPP})$ in $\mathrm{CHCl}_{3}\left(2 \times 10^{-6} \mathrm{~mol} \mathrm{~L}^{-1}\right)$ at $298 \mathrm{~K}, \lambda_{\mathrm{ex}}=420 \mathrm{~nm}$. 
porphyrins (4f, 4g, 4h and TPP) and zinc(II) porphyrins $(5,6$ and $\mathrm{Zn}-\mathrm{TPP}$ ) are shown in Figure 1a,b. Besides the Soret and Q bands in porphyrins $4 \mathrm{~g}, \mathbf{4 h}, \mathbf{5}$ and $\mathbf{6}$, an additional absorption peak originates at 280 and $320 \mathrm{~nm}$ due to the presence of pyrene and fluorene units, respectively. Thus, the electronic absorption spectra of these compounds demonstrated the features of both porphyrin and pyrene or fluorene subunits and suggest that there is no significant interaction between the attached chromophore and the porphyrin ring in the ground state.

The fluorescence spectra of porphyrins $4 f, 4 g, 4 h, 5$ and 6 were recorded in $\mathrm{CHCl}_{3}$ at the excitation wavelength of $420 \mathrm{~nm}$ and are shown in Figure 1c,d. The free-base pyrrolo[1,2-a]quinoxalinoporphyrins $4 \mathbf{f}, \mathbf{4 g}$ and $\mathbf{4 h}$ displayed an emission band and a weak shoulder at $\sim 652$ and $\sim 717 \mathrm{~nm}$. These emission bands are found to be slightly intense in comparison to the TPP (Figure 1c). Similarly, the zinc(II) pyrrolo[1,2-a]quinoxalinoporphyrins 5 and $\mathbf{6}$ showed two fluorescence bands at $\sim 605$ and $\sim 652 \mathrm{~nm}$, which are also found to be slightly intense when compared to the emission bands of $\mathrm{Zn}-\mathrm{TPP}$ (Figure 1d).

\section{Conclusion}

In summary, the synthesis of two new porphyrin building blocks, 5-(3-nitro-4-(pyrrol-1-yl)phenyl)-10,15,20-triphenylporphyrin (2) and 5-(3-amino-4-(pyrrol-1-yl)phenyl)-10,15,20-triphenylporphyrin (3), has been accomplished in good yields. The porphyrin 3 was successfully utilized as starting material for the construction of a novel series of meso-substituted pyrrolo[1,2a] quinoxalinoporphyrins in $60-76 \%$ yields via TFA-catalyzed Pictet-Spengler cyclization with aromatic aldehydes followed by in situ oxidation in the presence of $\mathrm{KMnO}_{4}$. These porphyrin architectures may be useful as potential candidates for various biological evaluations.

\section{Supporting Information}

\section{Supporting Information File 1}

Experimental details and characterization data.

[http://www.beilstein-journals.org/bjoc/content/

supplementary/1860-5397-10-76-S1.pdf]

\section{Supporting Information File 2}

${ }^{1} \mathrm{H}$ and ${ }^{13} \mathrm{C}$ NMR spectra of newly synthesized compounds. [http://www.beilstein-journals.org/bjoc/content/ supplementary/1860-5397-10-76-S2.pdf]

\section{Acknowledgements}

We thank the University of Delhi, India for financial support. DKS is grateful to the Council of Scientific and Industrial Research, New Delhi, India for a junior Research Fellowship.
The JEOL ECX 400P (400 MHz) NMR facility at USIC, University of Delhi and SAIF, CDRI, Lucknow are acknowledged for providing the NMR and mass spectra, respectively.

\section{References}

1. Denisov, I. G.; Makris, T. M.; Sligar, S. G.; Schlichting, I. Chem. Rev. 2005, 105, 2253-2278. doi:10.1021/cr0307143

2. Gust, D.; Moore, T. A.; Moore, A. L. Acc. Chem. Res. 2001, 34, 40-48. doi:10.1021/ar9801301

3. Lindsey, J. S.; Mass, O.; Chen, C.-Y. New J. Chem. 2011, 35, 511-516. doi:10.1039/c0nj00977f

4. Imahori, H. J. Phys. Chem. B 2004, 108, 6130-6143. doi:10.1021/jp038036b

5. Barber, J. Chem. Soc. Rev. 2009, 38, 185-196. doi:10.1039/B802262N

6. Wong, W.-Y.; Harvey, P. D. Macromol. Rapid Commun. 2010, 31 , 671-713. doi:10.1002/marc.200900690

7. Chen, Y.-C.; Hsu, C.-Y.; Lin, R. Y.-Y.; Ho, K.-C.; Lin, J. T. ChemSusChem 2013, 6, 20-35. doi:10.1002/cssc.201200609

8. Ichiki, T.; Matsuo, Y.; Nakamura, E. Chem. Commun. 2013, 49, 279-281. doi:10.1039/c2cc36988e

9. Humphrey, J. L.; Kuciauskas, D. J. Am. Chem. Soc. 2006, 128, 3902-3903. doi:10.1021/ja0588353

10. Linke-Schaetzel, M.; Anson, C. E.; Powell, A. K.; Buth, G.; Palomares, E.; Durrant, J. D.; Balaban, T. S.; Lehn, J.-M. Chem.-Eur. J. 2006, 12, 1931-1940. doi:10.1002/chem.200500602

11. Liu, Z.; Yasseri, A. A.; Lindsey, J. S.; Bocian, D. F. Science 2003, 302, 1543-1545. doi:10.1126/science.1090677

12. Martin, R. E.; Diederich, F. Angew. Chem., Int. Ed. 1999, 38, 1350-1377. doi:10.1002/(SICI)1521-3773(19990517)38:10<1350::AID-ANIE1350>3 .0.CO;2-6

13. Conklin, D.; Nanayakkara, S.; Park, T.-H.; Lagadec, M. F.; Stecher, J. T.; Chen, X.; Therien, M. J.; Bonnell, D. A. ACS Nano 2013, 7, 4479-4486. doi:10.1021/nn401071d

14. Borek, C.; Hanson, K.; Djurovich, P. I.; Thompson, M. E.; Aznavour, K.; Bau, R.; Sun, Y.; Forrest, S. R.; Brooks, J.; Michalski, L.; Brown, J. Angew. Chem., Int. Ed. 2007, 46, 1109-1112. doi:10.1002/anie.200604240

15. Graham, K. R.; Yang, Y.; Sommer, J. R.; Shelton, A. H.; Schanze, K. S.; Xue, J.; Reynolds, J. R. Chem. Mater. 2011, 23, 5305-5312. doi:10.1021/cm202242x

16. Mori, H.; Tanaka, T.; Osuka, A. J. Mater. Chem. C 2013, 1 , 2500-2519. doi:10.1039/c3tc00932g

17. Jiao, C.; Huang, K.-W.; Chi, C.; Wu, J. J. Org. Chem. 2011, 76, 661-664. doi:10.1021/jo1019046

18. Jiao, C.; Zu, N.; Huang, K.-W.; Wang, P.; Wu, J. Org. Lett. 2011, 13, 3652-3655. doi:10.1021/ol201303h

19. Li, L.-L.; Diau, E. W.-G. Chem. Soc. Rev. 2013, 42, 291-304. doi:10.1039/c2cs35257e

20. Balaban, T. S. Acc. Chem. Res. 2005, 38, 612-623. doi:10.1021/ar040211z

21. Abdul Almohsin, S.; Cui, J. B. J. Phys. Chem. C 2012, 116, 9433-9438. doi:10.1021/jp301881s

22. Mozer, A. J.; Griffith, M. J.; Tsekouras, G.; Wagner, P.; Wallace, G. G.; Mori, S.; Sunahara, K.; Miyashita, M.; Earles, J. C.; Gordon, K. C.; Du, L.; Katoh, R.; Furube, A.; Officer, D. L. J. Am. Chem. Soc. 2009, 131, 15621-15623. doi:10.1021/ja9057713

23. Tu, W.; Lei, J.; Wang, P.; Ju, H. Chem.-Eur. J. 2011, 17, 9440-9447. doi:10.1002/chem.201100577 
24. Wang, Q.; Lei, J.; Deng, S.; Zhang, L.; Ju, H. Chem. Commun. 2013, 49, 916-918. doi:10.1039/c2cc37664d

25. Lvova, L.; Di Natale, C.; Paolesse, R. Sens. Actuators, B 2013, 179, 21-31. doi:10.1016/j.snb.2012.10.014

26. Szabó, G.; Kiss, R.; Páyer-Lengyel, D.; Vukics, K.; Szikra, J.; Baki, A.; Molnár, L.; Fischer, J.; Keserü, G. M. Bioorg. Med. Chem. Lett. 2009, 19, 3471-3475. doi:10.1016/j.bmcl.2009.05.010

27. Guillon, J.; Dallemagne, P.; Pfeiffer, B.; Renard, P.; Manechez, D.; Kervran, A.; Rault, S. Eur. J. Med. Chem. 1998, 33, 293-308. doi:10.1016/S0223-5234(98)80063-9

28. Miyashiro, J.; Woods, K. W.; Park, C. H.; Liu, X.; Shi, Y.; Johnson, E. F.; Bouska, J. J.; Olson, A. M.; Luo, Y.; Fry, E. H.; Giranda, V. L.; Penning, T. D. Bioorg. Med. Chem. Lett. 2009, 19, 4050-4054. doi:10.1016/j.bmcl.2009.06.016

29. Milne, J.; Normington, K. D.; Milburn, M. Tetrahydroquinoxalinone sirtuin modulators. WO Patent WO2006094210 A2, Sept 8, 2006.

30. Desplat, V.; Moreau, S.; Gay, A.; Fabre, S. B.; Thiolat, D.; Massip, S.; Macky, G.; Godde, F.; Mossalayi, D.; Jarry, C.; Guillon, J. J. Enzyme Inhib. Med. Chem. 2010, 25, 204-215. doi:10.3109/14756360903169881

31. Fan, L.-L.; Huang, N.; Yang, R.-G.; He, S.-Z.; Yang, L.-M.; Xu, H.; Zheng, Y.-T. Lett. Drug Des. Discovery 2012, 9, 44-47. doi:10.2174/157018012798193026

32. Guillon, J.; Mouray, E.; Moreau, S.; Mullié, C.; Forfar, I.; Desplat, V.; Belisle-Fabre, S.; Pinaud, N.; Ravanello, F.; Le-Naour, A.; Léger, J.-M.; Gosmann, G.; Jarry, C.; Déléris, G.; Sonnet, P.; Grellier, P.

Eur. J. Med. Chem. 2011, 46, 2310-2326. doi:10.1016/j.ejmech.2011.03.014

33. van Heerden, L.; Cloete, T. T.; Breytenbach, J. W.; de Kock, C.; Smith, P. J.; Breytenbach, J. C.; N'Da, D. D. Eur. J. Med. Chem. 2012, 55, 335-345. doi:10.1016/j.ejmech.2012.07.037

34. Campiani, G.; Morelli, E.; Gemma, S.; Nacci, V.; Butini, S.; Hamon, M.; Novellino, E.; Greco, G.; Cagnotto, A.; Goegan, M.; Cervo, L.; Dalla Valle, F.; Fracasso, C.; Caccia, S.; Mennini, T. J. Med. Chem. 1999, 42, 4362-4379. doi:10.1021/jm990151g

35. Katounina, T.; Besret, L.; Dhilly, M.; Petit-Taboué, M.-C.; Barbelivien, A.; Baron, J.-C.; Dauphin, F.; Barré, L. Bioorg. Med. Chem. 1998, 6, 789-795. doi:10.1016/S0968-0896(98)00035-2

36. Çarbas, B. B.; Kivrak, A.; Zora, M.; Önal, A. M. React. Funct. Polym. 2011, 71, 579-587. doi:10.1016/j.reactfunctpolym.2011.02.008

37. Achelle, S.; Baudequin, C.; Plé, N. Dyes Pigm. 2013, 98, 575-600. doi:10.1016/j.dyepig.2013.03.030

38. Panda, M. K.; Ladomenou, K.; Coutsolelos, A. G. Coord. Chem. Rev. 2012, 256, 2601-2627. doi:10.1016/j.ccr.2012.04.041

39. Son, H.-J.; Jin, S.; Patwardhan, S.; Wezenberg, S. J.; Jeong, N. C.; So, M.; Wilmer, C. E.; Sarjeant, A. A.; Schatz, G. C.; Snurr, R. Q.; Farha, O. K.; Wiederrecht, G. P.; Hupp, J. T. J. Am. Chem. Soc. 2013, 135, 862-869. doi:10.1021/ja310596a

40. Yang, J.; Yoon, M.-C.; Yoo, H.; Kim, P.; Kim, D. Chem. Soc. Rev. 2012, 41, 4808-4826. doi:10.1039/c2cs35022j

41. Sternberg, E. D.; Dolphin, D.; Brückner, C. Tetrahedron 1998, 54 , 4151-4202. doi:10.1016/S0040-4020(98)00015-5

42. Ballut, S.; Makky, A.; Chauvin, B.; Michel, J.-P.; Kasselouri, A.; Maillard, P.; Rosilio, V. Org. Biomol. Chem. 2012, 10, 4485-4495. doi:10.1039/c2ob25181g

43. Stamati, I.; Kuimova, M. K.; Lion, M.; Yahioglu, G.; Phillips, D.; Deonarain, M. P. Photochem. Photobiol. Sci. 2010, 9, 1033-1041. doi:10.1039/c0pp00038h
44. Sharma, S.; Nath, M. New J. Chem. 2011, 35, 1630-1639. doi:10.1039/c1nj20248k

45. Sharma, S.; Nath, M. J. Heterocycl. Chem. 2012, 49, 88-92. doi:10.1002/jhet.664

46. Sharma, S.; Nath, M. Dyes Pigm. 2012, 92, 1241-1249. doi:10.1016/j.dyepig.2011.07.022

47. Bhatt, R. K.; Sharma, S.; Nath, M. Monatsh. Chem. 2012, 143 309-316. doi:10.1007/s00706-011-0625-0

48. Sharma, S.; Nath, M. Beilstein J. Org. Chem. 2013, 9, 496-502. doi:10.3762/bjoc.9.53

49. Zhang, H.-L.; Shi, W.-M.; Wu, J. Heterocycles 2005, 65, 3001-3006. doi:10.3987/COM-05-10555

50. Cox, E. D.; Cook, J. M. Chem. Rev. 1995, 95, 1797-1842. doi:10.1021/cr00038a004

51. Agarwal, P. K.; Sawant, D.; Sharma, S.; Kundu, B. Eur. J. Org. Chem. 2009, 292-303. doi:10.1002/ejoc.200800929

\section{License and Terms}

This is an Open Access article under the terms of the Creative Commons Attribution License

(http://creativecommons.org/licenses/by/2.0), which permits unrestricted use, distribution, and reproduction in any medium, provided the original work is properly cited.

The license is subject to the Beilstein Journal of Organic Chemistry terms and conditions:

(http://www.beilstein-journals.org/bjoc)

The definitive version of this article is the electronic one which can be found at: doi: $10.3762 /$ bjoc. 10.76 